\title{
FEEDING PATTERN OF SEPIA OFFICINALIS (CEPHALOPODA: SEPIODIDEA) IN THE RIA DE VIGO (NW SPAIN)
}

\author{
B.G. CASTRO AND A. GUERRA \\ Instituto de Investigaciones Marinas, Muelle de Bouzas s/n, 36208 Vigo, Spain
}

(Figures 1-3)

\begin{abstract}
The feeding pattern of Sepia officinalis was studied from field data obtained in two $24 \mathrm{~h}$ sampling operations carried out in August and February. The August results showed a $24 \mathrm{~h}$ feeding pattern in which most feeding occurred during darkness. The increase in feeding coincided with dusk and the first hours of darkness. In February there was no clear discontinuity in the feeding pattern but, as in August, the greatest incidence of empty guts was between noon and dusk. The fullness index was 3\% in August and 1.7\% in February.
\end{abstract}

\section{INTRODUCTION}

The importance of feeding pattern is well documented in fish (Jenkins \& Green, 1977; Simenstad \& Cailliet, 1986) but there are not many reported studies in cephalopods. Feeding patterns, as defined by Jenkins \& Green (1977) have been studied, to our knowledge, only in Todarodes pacificus (Okiyama, 1965), Loligo pealei (Vovk, 1972), Loligo opalescens (Karpov \& Cailliet, 1978), Mllex illecebrosus (Amaratunga et al., 1979; Amaratunga, 1980) and Nototodarus gouldi (O'Sullivan \& Cullen, 1983). Boyle (1983) dealt with aspects of feeding in several cephalopod species but not specifically with feeding pattern. Aspects of feeding in Sepia officinalis have been reviewed by Nixon (1987). The present work describes the daily feeding pattern in Sepia officinalis from data collected in the field.

\section{MATERIAL AND METHODS}

A total of 255 specimens of Sepia officinalis were collected from the Ria de Vigo in two $24 \mathrm{~h}$ sampling operations carried out on 7 August 1986 and 26 February 1987. Sampling sites in the Ria are shown in Figure 1. The principal characteristics of the hauls, time intervals and number of specimens collected are given in Table 1.

Two different types of gear were employed; in August a beach seine of the type described by Arnaiz \& Coo (1977), and in February, a small otter trawl as described by Alonso-Allende \& Guerra (1984). Each haul lasted $15 \mathrm{~min}$. Bottom temperature was measured during each haul and is given in Table 1 . Low tides were at 0943 and $2216 \mathrm{~h}$ GMT in August, and at 0753 and $2005 \mathrm{~h}$ in February. There was a new moon on both occasions. Times of sunrise and sunset are indicated in Figure 2. 


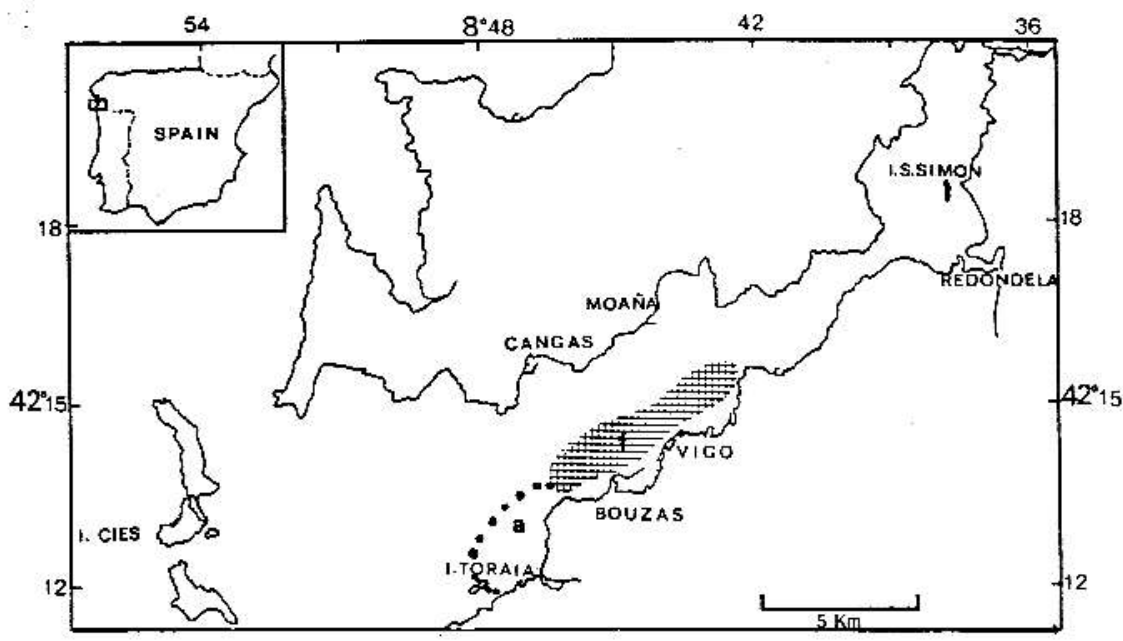

Figure 1. Map of Ria de Vigo showing the location of sampling sites in August (a) and in February (f).

Table 1. Characteristics of the hauls, specimens captured and bottom temperatures

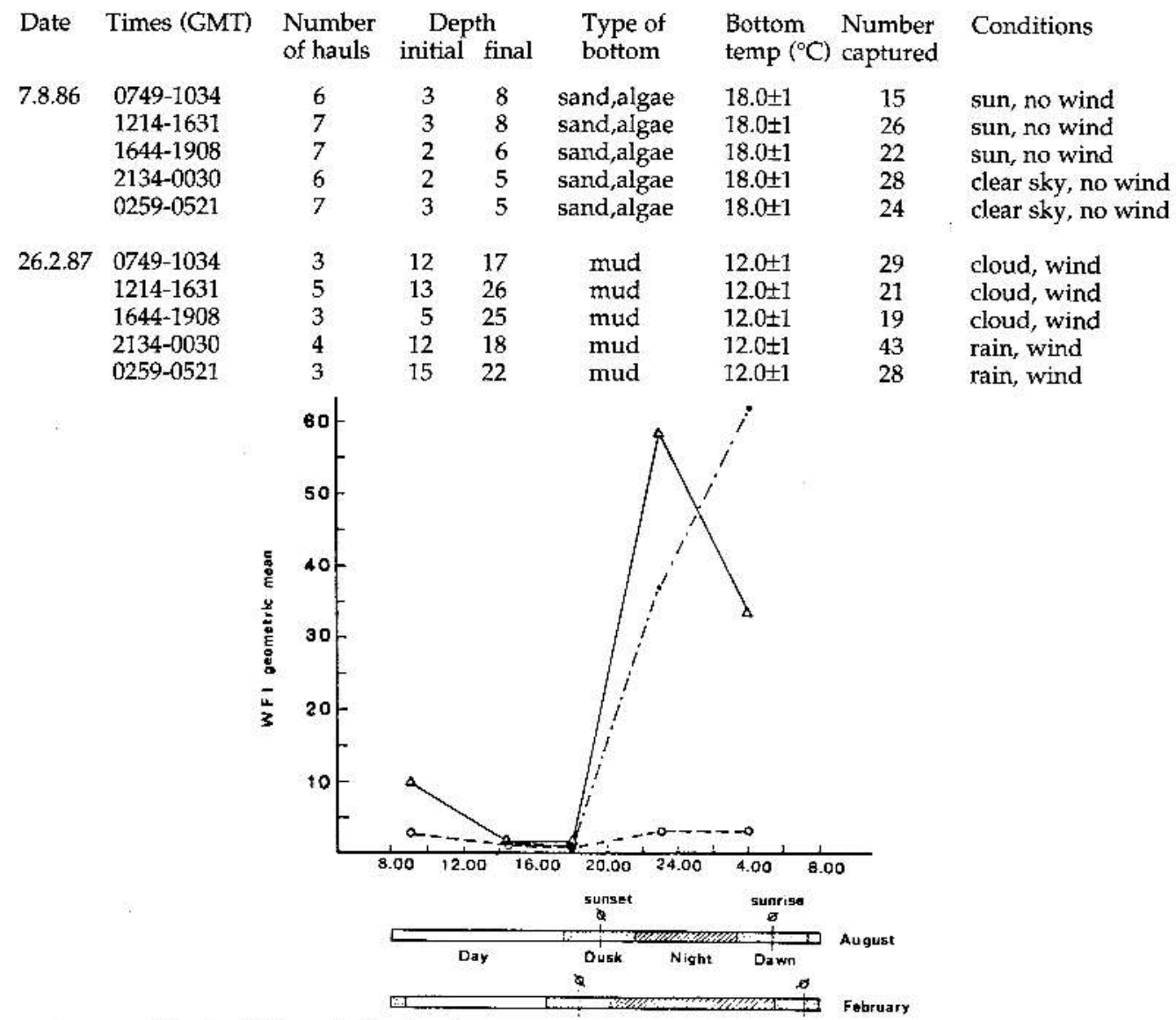

Figure 2. Weight Fullness Index (WFI) geometric mean variations in August specimens, ML $\leq 40 \mathrm{~mm}$ $(\bullet), M L>40 \mathrm{~mm}(\boldsymbol{\Delta})$ and in February $(\mathrm{O})$ 
Specimens were preserved on board at $4^{\circ} \mathrm{C}$ in ice boxes and all samples were stored at $-20^{\circ} \mathrm{C}$ in the laboratory. For analysis the individual blocks of frozen cuttlefish corresponding to each haul were thawed in tapwater at room temperature. Each specimen was numbered and the following parameters recorded.

1) Dorsal mantle length (ML) to the nearest $\mathrm{mm}$

2) Total drained wet body weight (BW)

3) Sex

4) Maturation stage. Scale 1-5 (immature to post spawning) by criteria essentially similar to those of Richard (1971) and Allonso-Allende \& Guerra (1984)

5) Gut fullness as subjective fullness index (SFI). Scale 0-4 (stomach empty to distended) by criteria similar to Amaratunga \& Durward (1979) and Hyslop (1980).

6) Weight of stomach contents (WSC) to nearest mg.

7) Stomach contents. Prey items identified to lowest taxon possible.

8) Digestive state index (DSI). Scale 1-4 (most digested to least digested) by criteria similar to Karpov \& Cailliet (1978).

The principal data of captured specimens is given in Table 2. For the August data the specimens are divided into two size groups (ML $\leq 40 \mathrm{~mm}$ and $M L>40 \mathrm{~mm}$ ). The smaller specimens were not taken in the February hauls due to the selectivity of the trawl which had a mesh size of $30 \mathrm{~mm}$.

Table 2. Principal data of specimens captured

\begin{tabular}{|c|c|c|c|c|c|c|c|c|c|c|}
\hline \multirow[t]{2}{*}{ Date } & \multirow[t]{2}{*}{$\begin{array}{l}\text { size } \\
(\mathrm{mm})\end{array}$} & \multirow[t]{2}{*}{ number } & \multirow[t]{2}{*}{$\begin{array}{l}\text { Mean ML } \\
\pm S D(m m)\end{array}$} & \multicolumn{3}{|c|}{ male female unsexed } & \multicolumn{4}{|c|}{$\begin{array}{l}\text { percentage in } \\
\text { maturation state }\end{array}$} \\
\hline & & & & & & & 1 & 2 & 3 & 4 \\
\hline 7.8 .86 & $10-40$ & 43 & $26.8(6.07)$ & 17 & 10 & 16 & 100 & 0 & 0 & 0 \\
\hline & $40-145$ & 72 & $95.3(15.7)$ & 29 & 43 & 0 & 15.4 & 60.3 & 16.6 & \\
\hline 26.2 .87 & $40-205$ & 140 & $84.2(36.8)$ & 54 & 86 & 0 & 10.7 & 48.8 & 9.3 & 31.2 \\
\hline
\end{tabular}

The weight fullness index (WFI $=$ WSC $\times 10000 / \mathrm{BW}$ ) was taken to be a standardised measure of fullness and is given in Table 3 for each category in the different fishing intervals. The fact that the variance of WSC is not wholly independent of BW renders this ratio unsuitable for parametric tests (Sokal \& Rohlf, 1969) and made it necessary to employ non-parameric tests (Siegel, 1959). The BW homogeneity of all specimens was tested using the Kruskal-Wallis test, adopting the significance level of $\alpha=0.05$ to reject the null hypothesis.

\section{RESULTS}

Table 3 summarizes the percentage of empty stomachs, those in the $1+2$ and $3+4$ digestive states and the values of weight fullness index for the five intervals considered for each date and the cuttlefish size classes. Figure 2 shows the variation of WFI geometric mean over 24 hours in August and February. Figure 3 shows the variation over $24 \mathrm{~h}$ in the percentage of empty stomachs and those in the different digestion states. 
Table 3. Percentages of empty stomachs, digestive state index and weight fullness index of specimens captured

\begin{tabular}{|c|c|c|c|c|c|c|c|c|c|}
\hline \multirow[t]{2}{*}{ Date } & \multirow{2}{*}{$\begin{array}{l}\text { Times } \\
\text { (GMT) }\end{array}$} & \multirow{2}{*}{$\begin{array}{l}\text { Size } \\
\text { class }\end{array}$} & \multirow{2}{*}{$\begin{array}{c}\text { No. of } \\
\text { stomachs }\end{array}$} & \multirow{2}{*}{$\underset{(\%)}{\text { Empty }}$} & \multirow{2}{*}{$\begin{array}{l}\text { DSI } \\
1 \& 2\end{array}$} & \multirow{2}{*}{$\begin{array}{l}\text { DSI } \\
3 \& 4\end{array}$} & \multicolumn{3}{|c|}{ WFI } \\
\hline & & & & & & & $\begin{array}{l}\text { Arith. } \\
\text { mean }\end{array}$ & Variance & $\begin{array}{l}\text { Geom. } \\
\text { mean }\end{array}$ \\
\hline 7.8 .86 & $0749-1034$ & $\leq 40$ & no data & - & - & - & - & - & - \\
\hline & $1214-1631$ & $\leq 40$ & 10 & 70.0 & 30.0 & 0 & 19.33 & 3141.50 & 1.20 \\
\hline & $1644-1908$ & $\leq 40$ & 12 & 83.33 & 08.33 & 08.33 & 09.58 & 703.66 & 0.91 \\
\hline & $2134-0030$ & $\leq 40$ & 14 & 14.28 & 85.72 & 0 & 90.73 & 9108.83 & 37.22 \\
\hline & $0259-0521$ & $\leq 40$ & 7 & 0 & 85.71 & 14.29 & 87.30 & 6607.46 & 62.04 \\
\hline & 0749-1034 & $>40$ & 15 & 26.67 & 60 & 13.33 & 23.85 & 786.71 & 9.86 \\
\hline & $1214-1631$ & $>40$ & 16 & 62.50 & 31.25 & 06.25 & 06.25 & 153.01 & 1.69 \\
\hline & $1644-1908$ & $>40$ & 10 & 70.50 & 20.00 & 10.00 & 08.62 & 441.31 & 1.45 \\
\hline & $2134-0030$ & $>40$ & 14 & 0 & 57.14 & 42,86 & 73.18 & 2452.57 & 58.72 \\
\hline & $0259-0521$ & $>40$ & 17 & 0 & 52.94 & 47.06 & 44.84 & 793.87 & 33.83 \\
\hline 26.2 .87 & 0749-1034 & $>40$ & 29 & 62.06 & 24.14 & 13.08 & 22.93 & 2136.98 & 2.88 \\
\hline & $1214-1631$ & $>40$ & 21 & 66.67 & 28.57 & 04.76 & 05.93 & 194.02 & 1.12 \\
\hline & $1644-1908$ & $>40$ & 19 & 73.69 & 15.78 & 05.27 & 10.19 & 883.99 & 0.86 \\
\hline & $2134-0030$ & $>40$ & 43 & 44.18 & 46.51 & 09.31 & 12.09 & 500.53 & 3.11 \\
\hline & $0259-0521$ & $>40$ & 28 & 53.57 & 21.43 & 25.00 & 22.04 & 1781.72 & 3.11 \\
\hline
\end{tabular}

Of the August catches, $44 \%$ of the smaller, and $28 \%$ of the larger animals had empty stomachs. The maximum value of WFI was 308 for the smaller, and 205 for the larger animals (or $3.08 \%$ and $2.05 \%$ of the body weight respectively), occurring in each case in the interval between 2134 and $0043 \mathrm{~h}$. Of the February catches $40.2 \%$ had empty stomachs and the maximum WFI was 165 (1.65\% of body weight) in the $0745-1043 \mathrm{~h}$ interval. In all cases where WFI was estimated the digestive state corresponded to DSI $=4$.

From the above there is a clear indication of a diurnal feeding pattern in which the onset of vigorous feeding activity occurs at dusk and may extend into the hours of darkness. This is seen most plainly in the graphs, except in the case of the weight fullness data for the February catches where the trend is only weak.

A

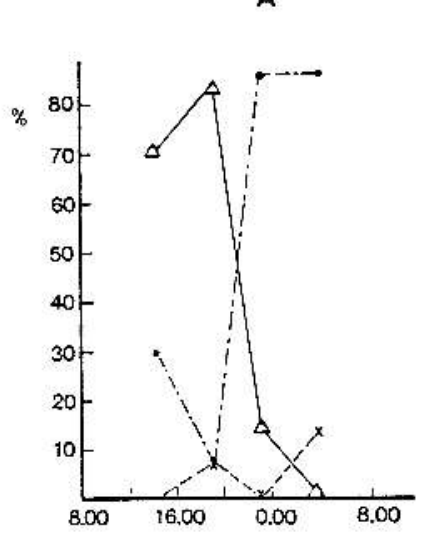

B

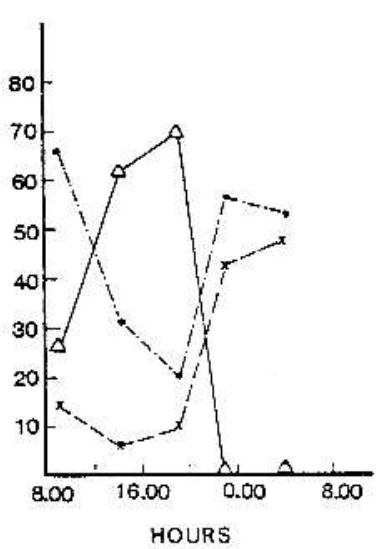

C

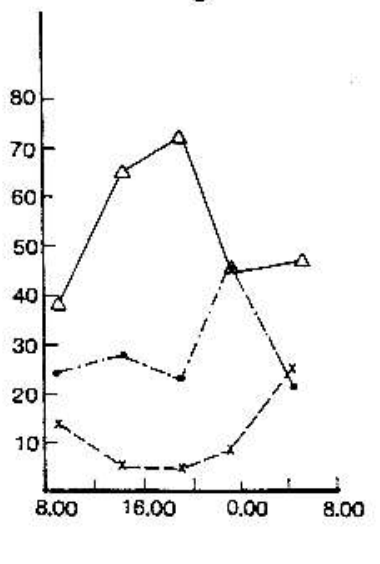

Figure 3. Percentage of empty stomachs $(\boldsymbol{A})$, stomachs with DSI $1 \& 2(\bullet)$, and $3 \& 4(\mathrm{x})$. (A) August specimens $M L \leq 40 \mathrm{~mm}$. (B) August specimens ML>40 mm. (C) February specimens (ML $>40 \mathrm{~mm}$ ). 


\section{Statistical tests}

Tables 4-7 show the results of non-parametric statistical tests made on the different sets of data to clarify the inference drawn above.

Table 4 shows the results of the Kruskal-Wallis test used to test for homogeneity in weight between fishing intervals for all specimens. Homogeneity was the null hypothesis. The results show that the specimens were homogeneous in weight, the required condition for valid comparison between the samples in different weight ranges.

Table 5 shows the results of the Kruskal-Wallis test applied to the WFI data as a test for feeding continuity. Feeding continuity was the null hypothesis. The results show discontinuous feeding in August but continuous feeding in February. Similar results were obtained using the SFI and DSI data.

Table 4. Values and significance of the Kruskal-Wallis test for homogeneity in weight of all specimens

$\begin{array}{lcccc}\text { Date } & \text { Size class }(\mathrm{mm}) & \text { FD } & H & \mathrm{H} \\ 7.8 .86 & \leq 40 & 3 & 0.36 & >0.05^{*} \\ & >40 & 4 & 6.88 & >0.05^{*} \\ 26.2 .87 & >40 & 4 & 3.04 & >0.05^{*}\end{array}$

* not significant

Table 5, Values and significance of the Kruskall-Wallis test for feeding continuity

$\begin{array}{lcccc}\text { Date } & \text { Size class }(\mathrm{mm}) & \text { FD } & \text { H } & P \\ 7.8 .86 & \leq 40 & 3 & 16.83 & <0.001 \\ & >40 & 4 & 43.49 & <0.001 \\ 26.2 .87 & >40 & 4 & 5.14 & >0.05^{*}\end{array}$

* not significant

Table 6. Results of $\chi^{2}$ test for feeding continuity based on DSI

$\begin{array}{lccc}\text { Date } & \text { Size class (mm) } & \text { FD } & P \\ 7.8 .86 & \leq 40 & 1 & <0.01 \\ & >40 & 4 & <0.001 \\ 26.2 .87 & >40 & 3 & >0.05^{*} \\ \text { * not significant } & & & \end{array}$

Table 6 shows the result of a $\chi^{2}$ test to ' $n$ ' independent samples using the digestive state index. For the test the data were grouped in the following way. Each size class of the August catches was divided into two groups comprising, (a) empty stomachs with DSI 1, and (b) DSI 2, 3 and 4. All five time intervals (Table 1) were used for specimens $>40 \mathrm{~mm}$. Only two time intervals (day and night) were considered in the case of the small specimens $\leq 40 \mathrm{~mm}$. The February catches were similarly grouped but the $2 \mathrm{nd}$ and 3rd time intervals were combined to give only four intervals.

Table 7 shows the results of the Mann-Whitney test used to test for significant difference of WFI between time intervals. For the small August specimens there was no significant difference between the two afternoon periods or between the two night 
Table 7. Results of Mann-Whitney test for differences in WFI between time intervals

\begin{tabular}{|c|c|c|c|c|c|c|}
\hline \multirow[t]{2}{*}{ Date } & $\begin{array}{l}\text { Size class } \\
(\mathrm{mm})\end{array}$ & $\begin{array}{c}\text { Time intervals } \\
\text { (GMT) }\end{array}$ & \multicolumn{4}{|c|}{ Time intervals (GMT) } \\
\hline & & & $1214-1631$ & $1644-1908$ & $2134-0030$ & 0259-0521 \\
\hline \multirow[t]{4}{*}{7.8 .86} & $\leq 40$ & 0749-1034 & 0 & 0 & 0 & 0 \\
\hline & & $1214-1631$ & & $p>0.05^{*}$ & $p<0.01$ & $p<0.01$ \\
\hline & & $1644-1908$ & & & $p<0.01$ & $p<0.01$ \\
\hline & & $2134-0030$ & & & & $p>0.05^{\star}$ \\
\hline \multirow[t]{4}{*}{7.8 .86} & $>40$ & $0749-1034$ & $p<0.01$ & $p<0.05$ & $\mathrm{p}<0.001$ & $\mathrm{p}<0.01$ \\
\hline & & $1214-1631$ & & $\mathrm{p}>0.05^{*}$ & $p<0.001$ & $\mathrm{p}<0.001$ \\
\hline & & $1644-1908$ & & & $p<0.001$ & $\mathrm{p}<0.001$ \\
\hline & & $2134-0030$ & & & & $p<0.05$ \\
\hline
\end{tabular}

periods. All other combinations showed a significant difference. In the case of the large specimens, only between the two afternoon periods was there no significant difference. For the February catches there was no significant difference between any of the time intervals. The same result was obtained when this test was applied to the subjective fullness index. Table 8 is a list of the prey species identified in the stomach contents by date and size class.

Table 8. Food items identified from stomachs of S. officinalis

\begin{tabular}{ll}
7.8 .86 & \multicolumn{1}{c}{7.8 .86} \\
ML $\leq 40$ & \multicolumn{1}{c}{ ML>40 } \\
Amphipoda & Palatmon Serratus \\
Processa sp. & Carcinus maenas \\
Palaemon sp. & Liocarcinus marmoreus \\
Crangon crangon & Pomatoschistus pictus \\
Portunidae & Aphia minuta \\
Pomatoschistus pictus & Lesuerigobius friesii \\
Aphia minuta & Gobius paganellus \\
Sygnathidae & Sygnathus typhle \\
& Symphodus sp. \\
& Ammodytidae \\
& Trachinus vipera \\
& Sepia officinalis
\end{tabular}

26.2 .87

$\mathrm{ML}>40$

Processa edulis

Crangon crangon

Palaemon sp.

Pisidia longicornis

Asthenognatus atianticus

Liocarcinus sp.

Polybius henslowi

Pomatoschistus pictus

Pomatoschistus minutus

Lesuerigobius friesii

Aphia minuta

Labriidae

Buglossidium luteum

Sepia sp.

\section{DISCUSSION}

From the literature it appears that there is no common feeding pattern among the cephalopods. Some species feed mainly during the daylight hours and others at sunset and during the night. The present results suggest that sunset is the principal exogenous stimulus to feeding in Sepia officinalis. This is in line with the observations of Denton \& Gilpin-Brown (1961) who showed that this species increases its bouyancy and is more active at night than in the day. Other benthic species show a similar behaviour. Johnson (1942) found that foraging is crepuscular or nocturnal in Octopus dofleini, Bergström (1985) observed that Sepietta oweniana feeds mainly at night and Shears (1988), from 
laboratory observations and from stomach contents of field specimens, found that Euprymna scolopes also feeds mainly at night.

There are some striking differences betwen the August and February results. We do not think that the different sampling methods used on the two occasions can have contributed to this because they affect only the size of the specimens captured. In the August results it is possible to examine the effect of size and it is apparent that there is no marked difference between the size groups. Spawning is another factor that might be expected to affect seasonal feeding activity but again we think that this was not a significant factor in the present investigation. Very few of the animals captured were close to spawing and, furthermore, from our own observations both in the field and with captive animals there is no reduction in feeding activity of Sepia officinalis before spawning. It is well known that in some inshore species the feeding rhythm is affected by the tides (cf. Wolff et al., 1980; Lagardère, 1987) but in the present data there is no indication of twelve hour peaks that would indicate a tidal effect.

It is likely that the results reflect a difference of prey availability between the two sampling occasions. Both the season and the different bottom substrate types could have contributed to differences in prey availability but it is not possible to separate the effects of these two factors in the present data. The bottom temperature in February was $6^{\circ} \mathrm{C}$ below that in August and would certainly have caused a reduction in activity and metabolic rate (Wolf et al., 1985) which may account for the greater number of empty stomachs and the smaller values for maximum WFI found in the winter catches. If the maximum WFI in the summer catches $3 \%$ and $2 \%$ for the smaller and larger size groups) represents the daily feeding ration, it is low compared with the 4-8\% we have found in tank experiments at the same temperature with similar animals in the $>40 \mathrm{~mm}$ size range. It is possible that very rapid digestion and absorption immediately after prey capture (Jobling, 1985) may lead to an underestimate of the daily food intake in the field samples.

The method of prey capture by Sepia officinalis is well known (Nixon, 1987). The species is a visual predator and Messenger (1977) found that attacks were not initiated in darknes or in dim red light. Nevertheless some of our specimens taken at $20 \mathrm{~m}$ depth in moonless and overcast conditions contained very recent prey in the stomach, which indicates that their night vision is very sensitive. Young (1963) described retinal dark adaptation in several cephalopod species including Sepia officinalis. In the case of Todarodes pacificus dark adaption is well documented (Suzuki et al., 1985). It occurs at about 1 lux, approximately the light intensity at the sea surface under a full moon, and $T$. pacificus will attack jiggs at 0.5 lux. Sepia officinalis may also detect prey such as prawns (Palaemon spp.) by light emitted from their light organs (Guerra, 1985). Finally, detection by chemoreception (Wells, 1966; Chase \& Wells, 1986) or by mechanoreception (Hanlon \& Budelmann, 1986) cannot be ruled out.

There are differences to be seen in Table 8 in the prey species taken by the $>40 \mathrm{~mm}$ samples in August and February. This is most likely due to the difference in bottom type at the two sampling sites. Some of the February prey species such as Carcinus meaenas, Liocarcinus marmoreus, Syngnathus typhle and Trachinus vipera do not occur in the deep muddy bottoms in the Ria de Vigo (Guerra et al., 1986) 
From the limited data set presented here there is a strong indication of a feeding pattern but more sampling would be needed to establish a true feeding pattern chronology (Jenkins \& Green, 1977).

The authors gratefully acknowledge the help of the crew of the 'San Juan', J.R. Caldas, $\mathrm{M}^{\mathrm{a}} \mathrm{T}$. Fernandez and F. Martinez for technical assistance. We would also like to thank Dr. PérezGándaras for his comments. This work was caried out with the financial support of CSIC and CAICYT.

\section{REFERENCES}

Alonso-Allende, J.M. \& Guerra, A., 1984. Crustáceos Décapodos y Moluscos Cefalópodos de la Ría de Vigo. In Diputación de Pontevedra. Premio Investigación 1984 (ed. pp. 1-152. Vigo: Instituto de Investigaciones Marinas.

Amaratunga, T., 1980. Preliminary estimates of predation by the short-finned squid (Illex illecebrosus) on the Scotian shelf. NAFO SCR Documents, 80/II/31. 1-13.

Amaratunga, T. \& Durward, R.D., 1979. Standardization of data collection for the short-finned squid Illex illecebrosus. ICNAF Selected Papers, 5, 37-41.

Amaratunga, T., Neilson, J.D., Gillis, D.J. \& Valdron, L.G., 1979. Food and feeding of the shortfinned squid Illex illecebrosus on the Scotian shelf in 1978. ICNAF Research Documents, 79/II/ $11,1-24$.

Arnaiz, R. \& Coo, A., 1977. Artes de marisqueo usadas en la Ría de Arosa. Plan de Explotación Marisquera de Galicia, 1-103.

Bergström, B., 1985. Aspect of natural foraging by Sepietta oweniana (Mollusca: Cephalopoda). Ophelia, 24, 65-74.

Boyle, P.R. (ed.), 1983. Cephalopod Life Cycles, vol. 1. Species Acounts. London: Academic Press.

Chase, R. \& Wells, M.J., 1986. Chemotactic behaviour in Octopus. Journal of Comparative Physiology, 158A, 375-381.

Denton, E.J. \& Gilpin-Brown, J.B., 1961. The buoyancy of the cuttlefish, Sepia officinalis (L.). Journal of the Marine Biological Association of the United Kingdom, 41, 319-342.

Guerra, A., 1985. Food of the cuttlefish Sepia officinalis and Sepia elegans in the Ria de Vigo (NW Spain) (Mollusca: Cephalopoda). Journal of Zoology (A), 207, 5111-519.

Guerra, A., Alonso-Allende, J.M., Pêrez-Gandaras, G., Ferreiro, M.J., Figueras, A.J. \& Labarta, U., 1986. Especies demersales y bentónicas de la Ría de Vigo. Pescas de arrastre (1982-84). Datos Informativos de Investigación Pesquera, no. 15, $188 \mathrm{pp}$.

Hanlon, R. \& Budelmann, B.-U., 1987. Why cephalopods are probably not 'deaf'. American Naturalist, 129, 312-317.

Hyslop, E.J., 1980. Stomach contents analysis - a review of methods and their application. Journal of Fish Biology, 17, 411-429.

Jenkins, B.W. \& Green, J.M., 1977. A critique of field methodology for determining fish feeding periodicity. Environmental Biology of Fishes, 1, 209-214.

Jobling, M., 1985. 'Digestion rate' methods for the estimation of daily ration of cephalopods. In Marine Biology of Polar Regions and Effects of Marine Organisms (ed. J.S. Gray and M.E. Kristensen), pp. 269-279. London: John Wiley \& Sons.

Johnson, M.W., 1942. Some observations on the feeding habits of Octopus. Science, New York, 95, 478-479.

Karpov, K.A. \& Cailliet, G.M., 1978. Feeding dynamics of Loligo opalescens. Fishery Bulletin. National Oceanic and Atmospheric Administration of the United States, 169, 45-65.

Lagardère, J.P., 1987. Feeding ecology and daily food consumption of common sole Solea vulgaris Quensel, juveniles on the French Atlantic coast. Journal of Fish Biology, 30, 91-104.

Messenger, J.B., 1977. Prey-capture and learning in the cuttlefish, Sepia. Symposia of the Zoological Society of London, no. 38, 347-376. 
Nixon, M., 1987. The diets of cephalopods. In Cephalopod Life Cycles, vol. 2 (ed. P.R. Boyle), pp. 201-219. London: Academic Press.

Okiyama, M., 1965. Some considerations on the eggs and larvae of the common squid Todarodes pacificus Steenstrup. Bulletin of the Japan Sea Regional Fisheries Research Laboratory, 15, 39-53.

O'Sullivan, D. \& Cullen, J.M., 1983. Food of the squid Nototodarus gouldi in Bass Strait. Australian Journal of Marine and Freshwater Research, 34, 261-285.

Richard, A., 1971. Contribution à l'Etude Expérimentale de la Croissance et de la Maturation Sexuelle de Sepia officinalis L. (Mollusque, Céphalopode). PhD thesis, Université Lille.

Shears, J., 1988. The use of a sand-coat in relation to feeding and diel activity in the sepiolid squid Euprymna scolopes. Malacologia, 29, 121-133.

Siegel, S., 1956. Nonparametric Statistics for the Behavioral Sciences. New York: McGraw-Hill Book Company.

Simenstad, C.H. \& Cailliet, G.M. (ed.), 1986. Contemporary Studies on Fish Feeding. Dordrecht: D. W. Junk Publishers.

Sokal, R.R. \& Rohlf, F.J., 1969. Biometry. San Francisco: W.H. Freeman \& Co.

Suzuki, T., Inada, H. \& Takahashi, H., 1985. Retinal adaptation of Japanese common squid (Todarodes pacificus Steenstrup) to light changes. Bulletin of the Faculty of Fisheries, Hokkaido University, 36, 191-199.

Vovk, A.N., 1972. Feeding habits of the North American squid Loligo pealei Les. Trudy Atlanticheskii Nauchno-Issledovatel'skii Institut Rybnogo Khozyaistva i Okeanografii, 42, 141-151.

WelIs, M.J., 1966. Cephalopod sense organs. In Physiology of Mollusca, vol. 2 (ed. K.M. Wilbur and C.M. Yonge), pp. 523-545. London: Academic Press.

Wolf, G., Vermeyen, E., Vlaeminck, A., Lemaire, J. \& Decleir, W., 1985. Respiration of Sepia officinalis during embryonic and early juvenile life. Marine Biology, 90, 35-39.

Wolff, W.J., Mandos, M.A. \& Sandee, A.J.J., 1980. Tidal migration of plaice and flounders as a feeding strategy. In Feeding and Survioal Strategies of Estuarine Organisms (ed. N.V. Jones and W.J. Wolff), pp. 159-172. New York: Plenum Press.

Young, J.Z., 1963. Light and dark-adaptation in the eyes of some cephalopods. Proceedings of the Zoological Society of London, 140, 255-272. 